\title{
Inhibitors in Building Students' Islamic Characters of Halal Tourism Destination at State Senior High School in East Lombok Regency
}

\author{
* Isni Mulyani ${ }^{1)}$ and Ratnawilis ${ }^{2)}$
}

1) Student Geography of Science, Padang State University, INDONESIA

2) Department of Geography, Universitas Negeri Padang-INDONESIA

Email: isni1993@gmail.com

*Corresponding Author, Received: January 15, 2018, Revised: March 02. 2018, Accepted: May 20, 2018

\begin{abstract}
This research was aimed to identify inhibiting factors of students' islamic character building at a senior high school in halal tourism destination area in East Lombok. The researcher used a Mix Method research for investigating the inhibitors. Then the priority of those factors were determined by using Urgency Seriousness Growth (USG) technique. To decide alternative solution of the factors the researcher employed Mc Namara which was used on the results obtained from Focus Group Discussion (FGD). The research population was SMA Negeri 1 Sembalun which is located in an area recognized as World's Best Halal Honeymoon Destination by World Halal Tourism Awards in 2016.The sample of qualitative research was chosen through snowball sampling technique on students of senior high schools in East Lombok. Meanwhile, the quantitative research population was all schools 'teachers and the head masters and the sample was chosen by using purposive sampling technique. The qualitative sample generalized the inhibiting factors and provided alternative solutions of the problems. This research can be source information and suggestion in building students' Islamic character especially in areas with halal tourism potentials. As for teachers it can be a reference and additional knowledge especially in solving the problems in building the characters. Furthermore, it also becomes a consideration to help improving the quality of geography learning especially for the sake of student's Islamic character building.
\end{abstract}

Keywords: Inhibitors, Student's Islamic Character Building, Halal Tourism Destination

\section{Introduction}

Education means conscious and well-planned effort in creating a learning environment and learning process so that learners will be able to develop their full potential for acquiring spiritual and religious strengths, develop self-control, personality, intelligence, morals and noble character and skills that one needs for him/herself, for the community, for the nation, and for the State (UU No. 20 Tahun 2003). Ki Hajar Dewantara stated that Education is a guide in the lives of children. In other words, Education guides the nature of children so that as humans and members of the society they will be able to obtain happiness and safety as high as possible (Hasbullah, 2009:4). This indicates that education is an effort to improve students' potentials to have intelligence and strong characters.

Asymanidar et al., (2013) suggests geography as one of high school subjects thatplay a rolein instilling positive values or characters in students. One of the characters is Islamic character. Judging from its implementation and its value, islamic character is no different fromcharacter values set by the government although in its implementation, islamic values are born from Al-Quran dan Sunnah (Rahardja and Zaenal Arifin, 2017). In Permendikbud Number 24 Year 2016 the purpose of curriculum 2013 covers four 
competences which are (1) spiritual attitude, (2) social attitude, (3) knowledge, and (4) skill. Islamic character building is needed in geography learning in orderto havethe competences of spiritual attitude and social attitude as mentioned as follows:

Table I. The Formulation of The Competences of Spiritual and Social Attitude

\begin{tabular}{ll}
\hline \multicolumn{1}{c}{ Core competences } & \multicolumn{1}{c}{ Formulation } \\
\hline Spiritual Competence & $\begin{array}{l}\text { To live and practice the teachings of religion adopted by } \\
\text { student }\end{array}$ \\
\hline Social competence & $\begin{array}{l}\text { To show students'behaviors of honesty, discipline, } \\
\text { responsibility, careness (community self-help, cooperation, } \\
\text { tolerance and peace), politeness, responsiveness, and } \\
\text { proactiveness as partial solutionsof various problems in } \\
\text { creating effective interaction with social and natural } \\
\text { environment and to position themselves as a reflection of the } \\
\text { nation in world association. }\end{array}$ \\
\hline
\end{tabular}

Source: Permendikbud Number 24 Year 2016

Both competences are achieved through indirect learning such as exemplary, habituation, school culture by considering the characteristics of subject and students' needs and condition. Character is also related to behavior. In this context Wening (2012) in Sugandi (2015) explained thatone's behavior is determined by environmental factor, with conditioning as its theoritical basis. In line with Wening (1986) stated that human self development is affected by the human it self and its environment. East Lombok Lombok Regency of Nusa Tenggara Barat is one of regions degraded as international halal tourism. Halal tourism has become a part of national tourism industry which aims to make Indonesia as the center of world halal tourism in the future. Award earned by Nusa Tenggara Barat in World Halal Tourism Award 2016 regards Indonesia as World's Best Halal Honeymoon Destination: Sembalun Village, Lombok, NTB, Indonesia and World's Best Halal Beach Resort: Novotel Lombok Resort and Villas, Lombok, NTB (Jaelani, 2017:15). WTM (2007) explained that halal tourism as religious tourism is in accordance with Islamic principles regarding attitude, fashion, and other activities. Moreover, Islamic tourism attracts many tourists through its Islamic culture (Henderson, 2009; Javed, 2007).

Another definition of halal tourism is "attractions or actions allowed by islamic teachings which are used and included by Moslems in tourism industry". That definition consideres sharia law as a basis in offering tourism products and services to customers who are mostly Moslems such as Syariah Compliant Hotel, halal resort, halal restaurant, and halal trip. The definition also indicates that the location of activities is not limited in the moslem world. Thus, halal tourism also includes services and products designed for moslems with nonreligious travelling purpose (Battour dan Mohd Nazari Islamail, 2015). The area of halal tourist destination in East Lombok becomes the driving force for students to have an Islamic character. Because the Islamic-based environment has a positive impact on students. And with the existence of tourism activities and objects, students actually have a source of learning geography. Geography learning material needs to be adjusted to the physical and social conditions in the student's environment, so that the student's learning environment can be used as a learning resource (Sugandi, 2013).

In addition to the function as the source of geography learning the existence of the halal tourism area requires students to have Islamic characters. This is because "islamic" means to have characteristics, attitudes, and behaviors which are based on the concept of an ideal moslem mentioned in the Quran. By those islamic characters a moslem is expected to be a devotee who practices Allah's command in His guidances (Johansyah, 2011). There are many verses in the Quran that mention geographical science, for example the verses that tell about the creation process of universe, sky and earth, wind, cloud, mountains, natural rerources, and even the origin of universe. It means that Islamic character building which is based on the Quran is very suitable for students especially in geography learning. So students will have a good character to protect nature and the mentioned purpose of curriculum 2013 can be achieved

The benefits of this study are suggestions and considerations (reference) for building islamic characters of state senior high school students in East Lombok Regency, and references and sources to improve teachers' understanding about factors that could inhibit students' islamic character building. As for related parties, this research can be a reference or consideration to help improving the quality of Geography teachinglearning especially in building students islamic character. 


\section{Method}

This research employed mixed method research. Mixed method consists of two methods or more which is usually used through two different approaches, namely quantitative or qualitative (vice versa) in a research and aimed to obtain quantitative and qualitative data used as empirical evidence for answering research questions so that the researcher can obtain complete, better and comprehensive result (Sarwono, 2011:2). Qualitative method was used for revealing the factual information of inhibiting factors of student's Islamic character building. In this case, the researcher determined research population according to halal tourism destination area in East Lombok Regency and chose Sembalun District as the research setting. This area was recognized as World's Best Halal Honeymoon Destination by World Halal Tourism Awards in 2016. It has a senior high school named SMA N 1 Sembalun whose most of the students live in Sembalun Distritc of East Lombok. The population of qualitative research was all its Social majored students (see table 2). The technique of sampling was Snowball Sampling. First, the researcher chose two students to collect the data. However, since the data from them was not enough, she seek other students who were considered to have more information and be able to make up the data from previous students. And it goes on until the sample becomes more and more (Sugiyono, 2015). Meanwhile, a quantitative method was used for generalizing the inhibitors and deciding alternative solutions of the problems found in the research. Its population was teachers of state senior high schools in East Lombok Regency and the sample was Geography teachers and the head masters of some high schools in East Lombok, namely SMA N 1 Sikur, SMA N 1 Montong Gading and SMA N 1 Sembalun. The sample was chosen through Purposive sampling. According to Sugiyono (2012) Purposive Sampling is a technique of determining sample with certain considerations. Data was analysed through scoring followed by data reduction, data interpretation, data display and conclusion. After knowing the inhibitors of students' islamic character building, the data was analysed by using Urgency Seriousness Growth (USG) technique to determine the prioritized factors. "USG is an intrument to arrange the order of priority issued to be solved" (State Administrative Institution of RI, 2008: 16). The next step is determining alternative solution for those inhibitors. To do that, the researcher used Mc. Namara technique on the resut of Focus Group Discussion (FGD).

\section{Results and Discussion}

\section{Inhibitors of Students' Islamic Character Building regarding Time Utilization}

Firstly, the researcher identified time allocation utilized by teachers in embedding islamic character in students. To collect the data, the researcher observe Lesson Plan used by Geography teachers. The result from observation showed that Geography teachers of senior high schools in East Lombok Regency generally taught about islamic character to students at the beginning and the end of teaching and learning activity and the teachers also inserted islamic character values in Geography lesson materials.

Table 2. Effort to Build Student's Islamic Character in Geography Lesson (time allocation)

\begin{tabular}{ll}
\hline \multicolumn{1}{c}{ Time Allocation of Geography Lesson } & \multicolumn{1}{c}{ Effort to Build Student's Islamic Character } \\
\hline Introductory Activity & $\begin{array}{l}\text { Praying, reciting verses of the Quran, and doing apperception } \\
\text { followed by motivating students to have morals and noble } \\
\text { characters in accordance with the teaching of Quran }\end{array}$ \\
\hline Main Activity & Relating Geography materials with islamic values \\
\hline Closure & $\begin{array}{l}\text { Reciting short surahs of the Quran if Geography class is last } \\
\text { lesson of the day } \\
\text { Evaluating the lesson and motivating the students to develop } \\
\text { good morals in learning Geography }\end{array}$ \\
\hline
\end{tabular}

Other than mentioned effort in Table 2, the school also attempted to build the character through IMTAQ program every Friday, Zuhur praying in Congregation, reading the Quran, holding religious event to commemorate islamic histories and teacher's example of islamic characters. Those efforts argued that had 
made an effort to build students' islamic character. However, there found some students whose attitudes and morals did not reflect islamic character and teacher's and school's efforts were not fully realized. Inhibing factors or inhibitors are:

a. Limited time

The result shows that applicable time allocation has not yet been maximally used for building students Islamic character. The result can be seen in Graph 1. There are three indicators of time allocation to be analyzed. First, goal achievement of students' islamic character building. Bandura Locke and Latham in Macan (1994) stated that "Goal setting relates to its effectiveness on one's behavior". The purpose of islamic character building should be understood, whether it is achieved or not in teaching and learning process of Geography and in the outside of the class since the two activities describe all ongoing process and actions in building student's islamic character. Second, time management in building students' islamic character. By having enough time allocation and rosources, the researcher was eager to know the achievement of Geography lesson plan and timetable and extracurricular activities in building student's islamic character. The last indicator is preference of islamic character building for Geography teaching and learning process and extracurricular activities. In other words, the time was not maximally allocated for building students' islamic character both in Geography classes or in extracurricular activities. Based on the qualitative data, inhibiting factor of the mentioned three indicators is limited time. Geography teaching and learning process takes a lot of time whether teaching the materials or teaching islamic character to students. In addition, teachers were having difficulties in designing Lesson Plan especially one which was based on curriculum 2013. The revision of old curriculum (KTSP) into curriculum 2013 which demands students to have many competencies makes teachers difficult to design and arrange the lesson because of limited time allocation.

b. Students' lack of religious bacground knowledge

Students were not confident in applying islamic character values because they had little knowledge about the religion. The result from interview showed that in Sembalun District, its young generations especially students of SMA Negeri 1 Sembalun were less motivated to be good at reading the Quran despite it's popularity as halal tourism destination area. Students who were not good at reading the Quran difficultly followed islamic character building activities held by teachers and the principle. This becomes the reason of students' uncertainty in building the character in themselves.

c. Studens did not maximally use the times provided for Islamic character building

As world's best halal honeymoon destination, Sembalun gains world attention and attracts local and foreign tourists to come to Sembalun. The arrival of tourists give positive and negative effect on students who live in this halal tourism destination area. One of positive effects is increasing local people's economy since the tourists need services from the locals. Based on the result from interview with Geography teachers, it was found that before semester examination weeks somes students were absent due to their sudden part-time job as Tour Guide and Porter. The students earned much money from the tourists especially foreign ones. In addition, the principle explained that some students were from a low economic family thus they chose the job over school in order to help their family by taking advantage potential income in East Lombok' halal tourism destination.

\section{Inhibitors of students' Islamic character building regarding school facilities and infrastructures}

Facilities and infrastructures help and support islamic character building in students. They also have a big role in determining the success of islamic character building and supporting learning quality. However, in Graph 2, it is showed that facilities and infrastructures in SMA Negeri 1 Sembalun are inadequate and did not fully support islamic character building. The information obtained from interview with Geography teachers revealed that there were very vew useful learning equipment, props and instructional media to support students' islamic character building for example the absence of books that contain both Geography materials and islamic character values. A Geography subject that includes Islamic character values can shape students' personality as a good caliph on earth and educate students to care for and be aware of their environment. Moreover, the facilities such as classroom, school field, praying place, and place for ablution should be improved because those are served as laboratory for students to apply islamic character values. 


\section{Inhibitors of Students' Islamic Character Building regarding Teacher's creativity}

Teacher's creativity in building students' islamic character means giving a good role model. The data of this research found that teachers' and staffs' role models could be loving their job as educators, having educational personality, good at operate the technology, taking advantage of the limitations, open minded, loving the challange, good at communication, loving to read books, future oriented, and developing religiousity. These role models are tips for teachers in SMA Negeri 1 Sembalun to be creative. Unfortunately, the result of this research showed that there were factors that inhibited teachers' creativity in building students Islamic characters in this halal toursim destination. The inhibiting factors are:

\section{Limited facilities, infrstructures and time for teacher's creativity}

From analyses of time and facility and infrastructure, there were limited supports for Islamic character building and this influenced teachers' creativity. The data revealed that limited time resulted in teachers' difficulty in building students' islamic character and ineffective and inefficient character building process in classroom and outside of classroom. Observation and interview results revealed students' low learning interest. Students tended to be lazy to learn both at school and their houses. They hardly reviewed the lesson given by Geography teachers in the classromm so they tended to cheat in the test. Cheating was prohibited since it negatively affects students' mental state especially those who tried hard in learning. Then, students were not aware of their lack of knowledge. For example, a student who could not read the Quran fluently did not want to learn from the more fluent ones. Students were very passive. They just relied on what given by teachers and their school and did not try to study hard outside of the school. These behaviors are not of islamic characters. Islamic halal tourism destination based islamic character building expected the students to have a character of a devout muslim, be discipline, pay attention to the fulfillment of life needs, morals and noble characters and preserve the environment. Students who do not love knowledge will not aware of their weaknesses that make them difficult to be a devout muslim. Moreover, students' behavior of cheating told that they were not disciplined and did not care to fulfill their life needs. On the contrary, students' high interest in learning reflects their good morals and noble characters. With students' high knowledge, they will be able to care for their environment as halal toursim destination.

Based on the data from Departement of Culture and Tourism (Disbudpar), it was found that tourist visits statistics for NTB was increasing during the last five years (2011-2015). The increasing number of national and international tourists in NTB Province was caused by the attraction of its halal toursim destination. Foreign tourists who visit the destination bring the culture from their home country and it directly and indirectly affects students who live in the destination area. In this research, the students were known to be vulnerable affected by foreign tourists' culture, for example their fashion and style which violate islamic teaching (shariah); haram (forbidden) foods and beverages, materialism; foreign culture that violates local courtesy and values. This influence could result in students' secular attitude, which means students prefer wordly life and ignore the religious values. In psychology, senior high school is where students grow to be teenager. Individually, teenagers are often uncomfortable doing what is required of them. However, due to the amount of pressure and desire to be acknowledged, the powerlesness to leave the group, and inability to say "NO" they are forced to do any demands given by the group. Over time this behavior becomes habitual and embedded into a character embodied in a variety of negative behaviors. Groups or peers have tremendous influence to determine the direction of adolescent life. If teenagers are exposed to an environment full of "negative energy" - for example foreign cultures - their behavior, attitude and purpose of life can be led into negative direction (Khotimah, 2014). If the negative culture is already on the students, teachers will need a long process and proper planning to build students' islamic character while on the other hand they also have to achieve Geography learning objectives. That's what keeps teachers from being creative in maximally building students' islamic character. 


\section{Inhibitor Priority of students' Islamic character building}

All the inhibiting factors of students' islamic character building activity in SMA Negeri 1 Sembalun had been revealed through this mixed method research. Those inhibitors should be solved especially by related parties. To make it easier, priority order of the inhibitors shoule be made. This priority orders will help us to singly solve the problem. Therefore, the next stage of data analysis used USG analysis technique. The procedures were determining the level of urgency, seriousness, and development of the inhibitors through using the value scale of 1-5. Highest scored inhibitors became the priority problems to be solved. Table 4 is the detail explanation of inhibitor priority of students' Islamic character building analysed by using USG technique.

\section{USG result shows that students' learning interest is the priority factor that inhibits students' islamic character building in halal toursim destination area.}

This problem should be solved in order to achieve maximum islamic character in students. To find alternative solution of the problems, the researcher used Mc. Namara tehcnique on the data obtained from Focus Group Discussion (FGD). FGD proposed some alternative solution. Then, from Mc. Namara analysis, four highest scored alternatives were chosen as solutions for the problem. Mc. Namara technique which is bases on three principles, effectivity, efficiency, and simplicity, can propose alternative solutions for the inhibitors of students' Islamic character building. Based on the scoring on alternative solutions conducted in FGD, there are four alternative solutions proposed by the technique. These solutions are expected to solve the major factors that responsible for disturbing the activity of Islamic character building in SMA Negeri of East Lombok Regency where halal tourism destinations are located. The four alternative solutions are:

a. At home, Parents pay attention by assisting the students in learning and involving in students' islamic character building

The importance of parental involvement in children's education has been widely recommended throughout the world. An effort that can be done by parents are through parents' education and assistance especially in children's Islamic character building. In Islam parents have a role to foster their child in order to be qualified person through a good effort. Prrophet Muhammad said, "the best gift given by parents to their children is education" (Al-Tarmidzi). Best effort that can be done by parents are education. Education can be given to children through parents' guidance and role model of Islamic character. Moreover, parents' involvement in students' learning development is able to give positive influence for students. Parents should be ready to help solving students' learning problems and difficuties. Kaukab (2016) in his study stated that "students' motivation, pride, and others are significantly related to parents involvement in students' academic and school and it also improve their motivation to perform as well as possible". The school should support parents-children relationship in their learning development in school especially in improving their interest to build Islamic character. Agood school is a school that involve parents in every school activity. Meeting between parents and tachers constributes in students' learning development. A communication between parents and teachers regarding learning development and condition of the students in school could give overall improvement in fostering the students (Kaukab, 2016).

b. Central and local government policy and investment in education in order to support students' learning interest especially their interest in islamic character building in halal tourism destination area

A poor character education causes many problems. Problems that arise in our society such as corruption, violence, sex crime, vandalism, mass fights, consumptive lifestyle, unproductive political life has been hot issues in many occasion. Many alternative solutions for national charater related issues have been proposed, for example national regulation and legislation and a serious effort to improve the application and the implemtation of firm laws. Another solution proposed to solve the problems is education. Education' role is as an alternative precaution to create a better generation. As an alternative precaution, education is expected to be able to improve the quality of young generation in many aspects so that the causes of national character related issues can be reduced (Saidek, 2016). In halal toursim destination area, policy that supports Islamic character based education should be made in order to maintain the morality of local people especially students. By doing so, students will not be contaminated by negative influence of foreign culture and affected by national charater related problems. 
c. Conducting Geography learning activity by using method which is consistent with students' ability and support their islamic character building

Students have different abilities in laerning the materials and understanding the meaning of Islamic character in Geography learning. Therefore, it needs appropriate methods for students' ability. One of methods is teaching Geography materials should be based on students' factual experience. Photography of East Lombok Regency can be a field of Geographic learning materi, and moreover tourists can also be real time learning resources for understanding cultures and social. By giving them a chance to understand Geography materials in the field, it will increase students' learning interest and belief in God Power.

d. Designing teaching materials that support islamic character building which are based on students' cognitive ability so that students can individually process the lesson and improve their self-motivation

Learning process needs effective communications between students and teacher. Teaching materials are means of communication that build student confidence in teacher. Teacher can design Geography teaching material inserted by Islamic character values that is consistent with students cognitive ability so that students are able to think individually and improves students' reading interest. In the last few decades, researchers found a reciprocal relationship between students' reading ability and their academic achievement (Hermida, 2009).

Secondary education plays a big role as a foundation of students' further education. If a good foundation is placed at the secondary school then students will be more prepared and easily overcoming the obstacles in lives and professions (Kpolovie et al., 2014). The four alternative solutions above can be served as good foundation for senior high school students in East Lombok to develop their Islamic character so that the competences of (1) spiritual attitude, (2) social attitude, (3) knowledge, and (4) skill in Geography learning can be done very well.

\section{Conclusion}

Inhibiting factors or inhibitors of students' Islamic character building at SMA Negeri 1 Sembalun located in a halal tourism destination area of East Lombok Regency are: (1) limited time; (2) students' lack of religious background knowledge; (3) Studens did not maximally use the times provided for Islamic character building; (4) inadequate facilities and infrastructures; (5) limited time, facility and infrastructure for teacher's creativity; (6) students' low learning interest; and (7) negative influence of foreign tourist culture. From USG analysis, the priority inhibitor of students' islamic character building were found to be students' low learning interest. Their low learning interest make them did not fully pay attention to maintain their sefl-quality. Islamic character aims to enable student to be qualified person in accordance with the teachings of Islam. If this problem is ignored, it will negatively affect students and local people. Four alternative solutions for increasing student's learning interest offered by Mc. Namara analysis are (1) At home, Parents pay attention by assisting the students in learning and involving in students' islamic character building; (2) Central and local government policy and investment in education in order to support students' learning interest especially their interest in islamic character building in halal tourism destination area; (3) Conducting Geography learning activity by using method which is consistent with students' ability and support their islamic character building; and (4) Designing teaching materials that support islamic character building which are based on students' cognitive ability so that students can individually process the lesson and improve their self-motivation. Halal Tourism potential in East Lombok Regency encourages students to have Islamic character and can be used as the source of geography learning materials. The existence of tourism attractions make students to have more understanding about physical and social phenomena occur around them. If students' Islamic character is equipped with geography knowledge, students will become humans with noble characters and who are able to protect their environments. 


\section{References}

Asymanidar. Dede Rohmat dan Mamat Ruhimat. (2013). Pengembangan Perangkat Pembelajaran Geografi Berbasis Pendidikan Karakter. Jurnal Pendidikan Geografi. Volume 13 (1): 1-12.

Battour, Mohammed and Mohd Nazari Ismail. (2015). Halal Tourism: Concepts, Practices, Challenges and Future. Article in Press Tourism Management Perspectives. www.elsevier.com/locate/tmp dan http://dx.doi.org/10.1016/j.tmp.2015.12.008. 1 Oktober 2017 (04:00).

Hasbullah. (2009). Dasar - Dasar Ilmu Pendidikan. Jakarta. Raja Grafindo Persada.

Hermida, Julian. (2009). The Importance of Teaching Academic Reading Skills in First Year University Courses. The International Journal of Research and Review. 3: 20-30. ISSN 2094-1420.

Jaelani, Aan. (2017). Halal Tourism Industry in Indonesia Potential and Prospects. Munich Personal RePEc Arcvhive. https://mpra.ub.uni-muenchen.de/76235/ dan iainanjal@gmail.com. 10 Oktober 2017 (12:53).

Johansyah. (2011). Pendidikan Karakter dalam Islam Kajian dari Aspek Metodologis. Jurnal Ilmiah Islam Futura. Volume XI (1) :85-103.

Kaukab, Syeda Rakhshanda. (2016). The Impact of Parent/Family Involment on Student Learning Outcomes. International Journal of Research Granthaalayah. 4 (10): 72-81. ISSN 2350-0530 (Online); ISSN 2394-3692 (Print).

Khotimah, Fitri Nur. (2014). Pengaruh Solidaritas Kelompok Teman Sebaya Terhadap Motivasi Belajar Siswa . http://repository.upi.edu/14723/6/. 7 Oktober 2017 (01:03)

Kpolovie, Peter James., Andy Igho Joe dan Tracy Okoto. (2014). Academic Achievement Prediction: Role of Interest in Learning and Attitude towards School. International Journal of Humanities Social Sciences and Education (IJHSSE). 1 (11): 73-100. ISSN 2439-0373 (Print); 2349-0381 (Online)

Macan, Therese Hoff. (1994). Time Management: Test of a Process Model. Journal of Applied Psychology. 79 (3): 381-391.

Rahardja, Bambang dan Zaenal Arifin. (2017). Implementasi Pendidikan Karakter Islami Pada Kegiatan Ekstrakulikuler "Hizbul Wathan" (Studi Empirik di SMA Muhammadiyah 3 Surakarta Tahun Pelajaran 2016/2017. Jurnal Suhuf. Volume 29 (2): 108-124.

Saidek, Abdul Rahim, Raisul Islami dan Abdoludin. (2016). Character Issues: Reality Character Problems and Solutions through Education in Indonesia. Journal of Education and Practice. 7 (17): 115-165.

Sarwono, Jonathan. (2011). Mixed Methods: Cara Menggabung Riset Kuantitatif dan Riset Kualitatif Secara Benar. Jakarta. Elex Media Komputindo.

Sujanto, Agus. (1986). Psikologi Pendidikan. Jakarta. Aksara Baru.

Sugandi, Dede. (2015). Pembelajaran Geografi Sebagai Salah Satu Dasar Pembentukan Karakter Bangsa. Jurnal Pendidikan Sains Sosial dan Kemanusiaan, 8(2) : 241-252. ISSN 1979-0112.

Sugiyono. (2012). Metode Penelitian Administrasi. Bandung. Alfabeta.

(2015). Metode Penelitian Pendidikan Pendekatan Kualitatif, Kuantitatif dan R\&D. Bandung. Alfabeta.

Undang - Undang Republik Indonesia Nomor 20 Tahun 2003 tentang Sistem Pendidikan Nasional. 2003. Dipublikasikan oleh https://kemenag.go.id/file/dokumen/UU2003 